Prepared for the U.S. Department of Energy

under Contract DE-AC05-76RL01830

\title{
NA-42 TI Shared Software Component Library FY2011 Final Report
}

CK Knudson

FC Rutz

KE Dorow

July 2011

Pacific Northwest

NATIONAL LABORATORY

Proudly Operated by Battelle Since 1965 


\title{
DISCLAIMER
}

This report was prepared as an account of work sponsored by an agency of the United States Government. Neither the United States Government nor any agency thereof, nor Battelle Memorial Institute, nor any of their employees, makes any warranty, express or implied, or assumes any legal liability or responsibility for the accuracy, completeness, or usefulness of any information, apparatus, product, or process disclosed, or represents that its use would not infringe privately owned rights. Reference herein to any specific commercial product, process, or service by trade name, trademark, manufacturer, or otherwise does not necessarily constitute or imply its endorsement, recommendation, or favoring by the United States Government or any agency thereof, or Battelle Memorial Institute. The views and opinions of authors expressed herein do not necessarily state or reflect those of the United States Government or any agency thereof.

\author{
PACIFIC NORTHWEST NATIONAL LABORATORY \\ operated by \\ BATTELLE \\ for the \\ UNITED STATES DEPARTMENT OF ENERGY \\ under Contract DE-AC05-76RL01830
}

Printed in the United States of America
Available to DOE and DOE contractors from the Office of Scientific and Technical Information,
P.O. Box 62, Oak Ridge, TN 37831-0062;
ph: (865) 576-8401
fax: $(865)$ 576-5728
email: reports@adonis.osti.gov

\begin{abstract}
Available to the public from the National Technical Information Service, U.S. Department of Commerce, 5285 Port Royal Rd., Springfield, VA 22161 ph: (800) 553-6847 fax: $(703) 605-6900$ email: orders@ntis.fedworld.gov online ordering: http://www.ntis.gov/ordering.htm
\end{abstract}

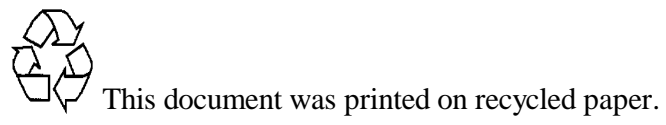




\title{
NA-42 TI Shared Software Component Library FY2011 Final Report
}

\author{
CK Knudson \\ FC Rutz \\ KE Dorow
}

July 2011

Prepared for the U.S. Department of Energy under Contract DE-AC05-76RL01830

Pacific Northwest National Laboratory

Richland, Washington 99352 


\subsection{Introduction}

The NA-42 TI program initiated an effort in FY2010 to standardize its software development efforts with the long term goal of migrating toward a software management approach that will allow for the sharing and reuse of code developed within the TI program, improve integration, ensure a level of software documentation, and reduce development costs. The Pacific Northwest National Laboratory (PNNL) has been tasked with two activities that support this mission.

PNNL has been tasked with the identification, selection, and implementation of a Shared Software Component Library. The intent of the library is to provide a common repository that is accessible by all authorized NA-42 software development teams. The repository facilitates software reuse through a searchable and easy to use web based interface. As software is submitted to the repository, the component registration process captures meta-data and provides version control for compiled libraries, documentation, and source code. This meta-data is then available for retrieval and review as part of library search results.

In FY2010, PNNL and staff from the Remote Sensing Laboratory (RSL) teamed up to develop a software application with the goal of replacing the aging Aerial Measuring System (AMS). The application under development includes an Advanced Visualization and Integration of Data (AVID) framework and associated AMS modules. Throughout development, PNNL and RSL have utilized a common AMS code repository for collaborative code development. The AMS repository is hosted by PNNL, is restricted to the project development team, is accessed via two different geographic locations and continues to be used. The knowledge gained from the collaboration and hosting of this repository in conjunction with PNNL software development and systems engineering capabilities were used in the selection of a package to be used in the implementation of the software component library on behalf of NA-42 TI.

The second task managed by PNNL is the development and continued maintenance of the NA-42 TI Software Development Questionnaire. This questionnaire is intended to help software development teams working under NA-42 TI in documenting their development activities. When sufficiently completed, the questionnaire illustrates that the software development activities recorded incorporate significant aspects of the software engineering lifecycle. The questionnaire template is updated as comments are received from NA-42 and/or its development teams and revised versions distributed to those using the questionnaire. PNNL also maintains a list of questionnaire recipients. 
The blank questionnaire template, the AVID and AMS software being developed, and the completed AVID AMS specific questionnaire are being used as the initial content to be established in the TI Component Library.

This report summarizes the approach taken to identify requirements, search for and evaluate technologies, and the approach taken for installation of the software needed to host the component library. Additionally, it defines the process by which users request access for the contribution and retrieval of library content.

\subsection{Assumptions}

It is expected that software development teams will maintain their own code repositories for use during development and management of their individual applications. The software component library is not intended to become the development environment for all projects but rather a repository where released versions of NA-42 TI program software packages and their associated documentation are stored for reference and available for re-use.

PNNL is responsible for hosting the software component library but does not have the responsibility of ensuring that all NA-42 software development teams comply with NA-42 guidance on the use of or access to the library.

\subsection{Requirements}

In order to perform an appropriate research and review of existing software packages, it was first necessary to define the functionality and capabilities that were required of the software to meet the needs of the program and the intended end users. Developing a well-defined set of software requirements prior to the initiation of the procurement process benefited the project in a number of ways. First, the requirements provided a consistent set of selection metrics for all staff members involved in the research phase of the procurement eliminating any misdirection and keeping staff members focused. Second, having a pre-defined set of requirements allowed staff members to quickly target prospective applications as well as quickly eliminating inappropriate applications both of which reduced the research and review time. Finally, the requirements provide a template for the testing of the software.

The requirements defined for the TI Shared Software Component Library were developed in three stages. During the first stage, potential categories of users who would be using the software were defined. 


\subsection{User Stories}

The user categories included developers, project managers, system administrators, and testers. The categories of developers and managers were further broken down to include users internal to PNNL and those outside of PNNL. Once the user roles were defined, stage two was to develop a set of user stories to illustrate the desired high level functionality of the software from the perspective of each user category. Table 1 lists the user stories developed for the shared software component library as well as the user categories associated with each story.

Table 1 Component library users and associated functions/stories.

\begin{tabular}{|c|c|c|c|c|c|c|c|c|}
\hline $\begin{array}{c}\text { Story } \\
\#\end{array}$ & $\begin{array}{c}\text { Function / User } \\
\text { Story }\end{array}$ & $\underset{\text { Mgmt }}{\text { TI }}$ & $\begin{array}{c}\text { Internal } \\
\text { Developer }\end{array}$ & $\begin{array}{c}\text { External } \\
\text { Developer }\end{array}$ & $\begin{array}{c}\text { Internal } \\
\text { PM }\end{array}$ & $\begin{array}{c}\text { External } \\
\text { PM }\end{array}$ & $\begin{array}{l}\text { System } \\
\text { Admin }\end{array}$ & Tester \\
\hline 1 & $\begin{array}{l}\text { I want to be able to } \\
\text { configure the library } \\
\text { so that it is accessible } \\
\text { by both internal and } \\
\text { external users } \\
\text { approved by NA-42 }\end{array}$ & & & & & & $\mathbf{X}$ & \\
\hline 2 & $\begin{array}{l}\text { I want to control } \\
\text { access to the library } \\
\text { based on roles and } \\
\text { responsibilities so I } \\
\text { know which users can } \\
\text { perform which tasks } \\
\text { and provide the } \\
\text { necessary } \\
\text { accountability }\end{array}$ & & & & & & $\mathbf{X}$ & \\
\hline 3 & $\begin{array}{l}\text { I need the library } \\
\text { capable of operating } \\
\text { on publicly available } \\
\text { servers so that it is } \\
\text { accessible by both } \\
\text { internally and } \\
\text { externally approved } \\
\text { NA-42 users }\end{array}$ & & & & & & $\mathbf{X}$ & \\
\hline 4 & $\begin{array}{l}\text { I need the library } \\
\text { capable of operating } \\
\text { on classified } \\
\text { networks as well as } \\
\text { non-classified } \\
\text { networks }\end{array}$ & $\mathbf{X}$ & & & $\mathbf{X}$ & $\mathbf{X}$ & $\mathbf{X}$ & \\
\hline 5 & $\begin{array}{l}\text { I need the library to } \\
\text { be developed by an } \\
\text { organization based } \\
\text { within the United }\end{array}$ & $\mathbf{X}$ & & & $\mathbf{X}$ & $\mathbf{X}$ & $\mathbf{X}$ & \\
\hline
\end{tabular}




\begin{tabular}{|c|c|c|c|c|c|c|c|c|}
\hline $\begin{array}{c}\text { Story } \\
\#\end{array}$ & $\begin{array}{c}\text { Function / User } \\
\text { Story }\end{array}$ & $\begin{array}{c}\text { TI } \\
\text { Mgmt }\end{array}$ & $\begin{array}{c}\text { Internal } \\
\text { Developer }\end{array}$ & $\begin{array}{c}\text { External } \\
\text { Developer }\end{array}$ & $\begin{array}{c}\text { Internal } \\
\text { PM }\end{array}$ & $\begin{array}{c}\text { External } \\
\text { PM }\end{array}$ & $\begin{array}{l}\text { System } \\
\text { Admin }\end{array}$ & Tester \\
\hline & States & & & & & & & \\
\hline 6 & $\begin{array}{l}\text { I need sufficient } \\
\text { configuration } \\
\text { management so I can } \\
\text { build any version of } \\
\text { the application } \\
\text { available within the } \\
\text { code library }\end{array}$ & & $\mathbf{X}$ & X & $\mathbf{X}$ & $\mathbf{X}$ & $\mathbf{X}$ & $\mathbf{X}$ \\
\hline 7 & $\begin{array}{l}\text { I need sufficient } \\
\text { configuration } \\
\text { management so I can } \\
\text { build new } \\
\text { applications using any } \\
\text { version of the } \\
\text { available software } \\
\text { modules within the } \\
\text { code library }\end{array}$ & & $\mathbf{X}$ & $\mathbf{X}$ & & & & $\mathbf{X}$ \\
\hline 8 & $\begin{array}{l}\text { I want a code } \\
\text { repository where } \\
\text { software applications } \\
\text { and modules can be } \\
\text { checked in so that } \\
\text { approved software } \\
\text { developers have them } \\
\text { available for review } \\
\text { use }\end{array}$ & $\mathbf{X}$ & $\mathbf{X}$ & $\mathbf{X}$ & $\mathbf{X}$ & $\mathbf{X}$ & $\mathbf{X}$ & $\mathbf{X}$ \\
\hline 9 & $\begin{array}{l}\text { I want to develop and } \\
\text { store the functions, } \\
\text { requirements, and } \\
\text { software applications } \\
\text { or modules in the } \\
\text { code repository so I } \\
\text { have traceability } \\
\text { between } \\
\text { customer/user inputs } \\
\text { and the code stored } \\
\text { in the library }\end{array}$ & $\mathbf{X}$ & $\mathbf{X}$ & $\mathbf{X}$ & $\mathbf{X}$ & $\mathbf{X}$ & $\mathbf{X}$ & $\mathbf{X}$ \\
\hline 10 & $\begin{array}{l}\text { I want a user } \\
\text { interface that } \\
\text { provides registration } \\
\text { so I can register new } \\
\text { components into the } \\
\text { library }\end{array}$ & $\mathbf{X}$ & $\mathbf{X}$ & $\mathbf{X}$ & $\mathbf{X}$ & $\mathbf{X}$ & $\mathbf{X}$ & $\mathbf{X}$ \\
\hline
\end{tabular}




\begin{tabular}{|c|c|c|c|c|c|c|c|c|}
\hline $\begin{array}{c}\text { Story } \\
\#\end{array}$ & $\begin{array}{c}\text { Function / User } \\
\text { Story }\end{array}$ & $\begin{array}{c}\text { TI } \\
\text { Mgmt }\end{array}$ & $\begin{array}{c}\text { Internal } \\
\text { Developer }\end{array}$ & $\begin{array}{c}\text { External } \\
\text { Developer }\end{array}$ & $\begin{array}{c}\text { Internal } \\
\text { PM }\end{array}$ & $\begin{array}{c}\text { External } \\
\text { PM }\end{array}$ & $\begin{array}{l}\text { System } \\
\text { Admin }\end{array}$ & Tester \\
\hline 11 & $\begin{array}{l}\text { I want a user } \\
\text { interface to check in } \\
\text { my contributions to } \\
\text { the library so I can } \\
\text { check in different } \\
\text { versions of code } \\
\text { modules, source code } \\
\text { and documentation }\end{array}$ & $\mathbf{X}$ & $\mathbf{X}$ & $\mathbf{X}$ & $\mathbf{X}$ & $\mathbf{X}$ & $\mathbf{X}$ & $\mathbf{X}$ \\
\hline 12 & $\begin{array}{l}\text { I want a library that } \\
\text { can store data sets so } \\
\text { I can store data from } \\
\text { common data } \\
\text { repositories }\end{array}$ & $\mathbf{X}$ & $\mathbf{X}$ & $\mathbf{X}$ & $\mathbf{X}$ & $\mathbf{X}$ & $\mathbf{X}$ & $\mathbf{X}$ \\
\hline 13 & $\begin{array}{l}\text { I want to know the } \\
\text { pedigree of the } \\
\text { software in the } \\
\text { repository so I can } \\
\text { choose the best } \\
\text { version of the } \\
\text { software to meet my } \\
\text { needs }\end{array}$ & $\mathbf{X}$ & $\mathbf{X}$ & $\mathbf{X}$ & $\mathbf{X}$ & $\mathbf{X}$ & $\mathbf{X}$ & $\mathbf{X}$ \\
\hline 14 & $\begin{array}{l}\text { I want pedigree } \\
\text { information to } \\
\text { differentiate between } \\
\text { versions of software } \\
\text { so my team can best } \\
\text { determine which } \\
\text { software to use }\end{array}$ & $\mathbf{X}$ & $\mathbf{X}$ & $\mathbf{X}$ & $\mathbf{X}$ & $\mathbf{X}$ & $\mathbf{X}$ & $\mathbf{X}$ \\
\hline 15 & $\begin{array}{l}\text { I want to know the } \\
\text { capabilities of the } \\
\text { code available for } \\
\text { reuse so we can write } \\
\text { project proposals that } \\
\text { include taking } \\
\text { advantage of existing } \\
\text { code }\end{array}$ & $\mathbf{X}$ & $\mathbf{X}$ & $\mathbf{X}$ & $\mathbf{X}$ & $\mathbf{X}$ & $\mathbf{X}$ & $\mathbf{X}$ \\
\hline 16 & $\begin{array}{l}\text { I want to search } \\
\text { through the library } \\
\text { documentation so } \\
\text { that I have a single } \\
\text { source to search for } \\
\text { reusable modules }\end{array}$ & $\mathbf{X}$ & $\mathbf{X}$ & $\mathbf{X}$ & $\mathbf{X}$ & $\mathbf{X}$ & $\mathbf{X}$ & $\mathbf{X}$ \\
\hline 17 & $\begin{array}{l}\text { I want to search } \\
\text { through the library } \\
\text { metadata so that I } \\
\text { have a single source } \\
\text { to search for reusable } \\
\text { modules }\end{array}$ & $\mathbf{X}$ & $\mathbf{X}$ & $\mathbf{X}$ & $\mathbf{X}$ & $\mathbf{X}$ & $\mathbf{X}$ & $\mathbf{X}$ \\
\hline
\end{tabular}




\begin{tabular}{|c|c|c|c|c|c|c|c|c|}
\hline $\begin{array}{c}\text { Story } \\
\#\end{array}$ & $\begin{array}{c}\text { Function / User } \\
\text { Story }\end{array}$ & $\begin{array}{c}\text { TI } \\
\text { Mgmt }\end{array}$ & $\begin{array}{c}\text { Internal } \\
\text { Developer }\end{array}$ & $\begin{array}{c}\text { External } \\
\text { Developer }\end{array}$ & $\begin{array}{c}\text { Internal } \\
\text { PM }\end{array}$ & $\begin{array}{c}\text { External } \\
\text { PM }\end{array}$ & $\begin{array}{l}\text { System } \\
\text { Admin }\end{array}$ & Tester \\
\hline 18 & $\begin{array}{l}\text { I want refined search } \\
\text { capabilities so I can } \\
\text { create detailed } \\
\text { technical descriptions } \\
\text { of code modules }\end{array}$ & $\mathbf{X}$ & $\mathbf{X}$ & $\mathbf{X}$ & $\mathbf{X}$ & $\mathbf{X}$ & $\mathbf{X}$ & $\mathbf{X}$ \\
\hline 19 & $\begin{array}{l}\text { I want to check } \\
\text { software into the } \\
\text { code library that has } \\
\text { been developed using } \\
\text { a development } \\
\text { environment of my } \\
\text { choice so that I have } \\
\text { a secure location for } \\
\text { my software. } \\
\text { Acceptance Criteria: } \\
\text { Developer checks in } \\
\text { code from a } \\
\text { framework that is } \\
\text { different than the } \\
\text { framework of the } \\
\text { code library }\end{array}$ & & $\mathbf{X}$ & $\mathbf{X}$ & & & & \\
\hline 20 & $\begin{array}{l}\text { I want to be notified } \\
\text { of new bugs against } \\
\text { the code my team is } \\
\text { responsible for when } \\
\text { they are created so I } \\
\text { can triage the bug and } \\
\text { determine a course of } \\
\text { action }\end{array}$ & & $\mathbf{X}$ & $\mathbf{X}$ & $\mathbf{X}$ & $\mathbf{X}$ & $\mathbf{X}$ & $\mathbf{X}$ \\
\hline 21 & $\begin{array}{l}\text { I want to have access } \\
\text { to the software bugs } \\
\text { that have been } \\
\text { submitted against the } \\
\text { code library so I have } \\
\text { additional } \\
\text { information to } \\
\text { determine the quality } \\
\text { of the software }\end{array}$ & & $\mathbf{X}$ & $\mathbf{X}$ & $\mathbf{X}$ & $\mathbf{X}$ & $\mathbf{X}$ & $\mathbf{X}$ \\
\hline 22 & $\begin{array}{l}\text { I want to have access } \\
\text { to the software bugs } \\
\text { that have been } \\
\text { submitted against the } \\
\text { code library so I can } \\
\text { determine which } \\
\text { software will be } \\
\text { further developed (or } \\
\text { improved upon) }\end{array}$ & $\mathbf{X}$ & & & $\mathbf{X}$ & $\mathbf{X}$ & $\mathbf{X}$ & $\mathbf{X}$ \\
\hline
\end{tabular}




\begin{tabular}{|c|c|c|c|c|c|c|c|c|}
\hline $\begin{array}{c}\text { Story } \\
\#\end{array}$ & $\begin{array}{c}\text { Function / User } \\
\text { Story }\end{array}$ & $\begin{array}{c}\text { TI } \\
\text { Mgmt }\end{array}$ & $\begin{array}{c}\text { Internal } \\
\text { Developer }\end{array}$ & $\begin{array}{c}\text { External } \\
\text { Developer }\end{array}$ & $\begin{array}{c}\text { Internal } \\
\text { PM }\end{array}$ & $\begin{array}{c}\text { External } \\
\text { PM }\end{array}$ & $\begin{array}{l}\text { System } \\
\text { Admin }\end{array}$ & Tester \\
\hline 23 & $\begin{array}{l}\text { I want to be able to } \\
\text { see what software } \\
\text { packages I have } \\
\text { stored in the } \\
\text { repository. }\end{array}$ & $\mathbf{X}$ & $\mathbf{X}$ & $\mathbf{X}$ & $\mathbf{X}$ & $\mathbf{X}$ & $\mathbf{X}$ & $\mathbf{X}$ \\
\hline 24 & $\begin{array}{l}\text { I want to be able to } \\
\text { access software } \\
\text { information/meta } \\
\text { data associated with } \\
\text { projects currently in } \\
\text { the webPMIS system. }\end{array}$ & $\mathbf{X}$ & & & $\mathbf{X}$ & $\mathbf{X}$ & $\mathbf{X}$ & \\
\hline 25 & $\begin{array}{l}\text { I want to be able to } \\
\text { have the system } \\
\text { admin restrict access } \\
\text { to certain codes } \\
\text { unless the user is } \\
\text { authorized by me }\end{array}$ & $\mathbf{X}$ & & & $\mathbf{X}$ & $\mathbf{X}$ & $\mathbf{X}$ & \\
\hline 26 & $\begin{array}{l}\text { I want to know the } \\
\text { system is secure and } \\
\text { cannot be penetrated } \\
\text { by outside threat }\end{array}$ & $\mathbf{X}$ & & & $\mathbf{X}$ & $\mathbf{X}$ & $\mathbf{X}$ & \\
\hline 27 & $\begin{array}{l}\text { Xn Roles... I want to } \\
\text { ensure that only } \\
\text { authorized individuals } \\
\text { have access to } \\
\text { content within the } \\
\text { code library and that } \\
\text { authorization will } \\
\text { follow a predefined } \\
\text { process agreed to by } \\
\text { NA-42 and PNNL } \\
\text { project management }\end{array}$ & $\mathbf{X}$ & & & $\mathbf{X}$ & $\mathbf{X}$ & $\mathbf{X}$ & \\
\hline 28 & $\begin{array}{l}\text { I want to be able to } \\
\text { place restrictions or } \\
\text { caveats on code my } \\
\text { team may include in } \\
\text { the library }\end{array}$ & $\mathbf{X}$ & & & $\mathbf{X}$ & $\mathbf{X}$ & $\mathbf{X}$ & \\
\hline
\end{tabular}

\subsection{Technical Requirements}

The last stage in the development of the software requirements was to break down each of the user stories into technical requirements for the software. These lower level requirements are intended to define the base functionality that the library software would need to meet. Table2 lists the requirements along with the number of the user story they are associated with. 
Table 2 Technical requirements and associated user stories.

\begin{tabular}{|c|c|}
\hline Story \# & Constraints / Requirements \\
\hline 1.1 & $\begin{array}{l}\text { The system shall provide a way to configure and control two factor authentication for } \\
\text { users external to PNNL who have been approved for access by NA- } 42\end{array}$ \\
\hline 1.2 & $\begin{array}{l}\text { The system shall provide a way to configure and control authentication for users } \\
\text { internal to PNNL who have been approved for access by NA- } 42\end{array}$ \\
\hline 2.1 & The system must control user access based upon role based authentication \\
\hline 2.2 & $\begin{array}{l}\text { The system must provide a graphical user's interface that allows an administrator to } \\
\text { quickly and easily set and update user accounts }\end{array}$ \\
\hline 3.1 & The system must be capable of running on servers outside of the PNNL firewall \\
\hline 3.2 & The system must run on commercially available server equipment \\
\hline 4.1 & $\begin{array}{l}\text { The software selected for use as the repository must be able to operate on classified and } \\
\text { non-classified networks }\end{array}$ \\
\hline 5.1 & $\begin{array}{l}\text { The software selected for use as the repository must not be developed or managed by a } \\
\text { company outside of the United States }\end{array}$ \\
\hline 6.1 & $\begin{array}{l}\text { The software selected for use as the repository must be able to store and maintain } \\
\text { different versions of each of the files and projects in the repository }\end{array}$ \\
\hline 6.2 & $\begin{array}{l}\text { The software must be able to correlate all stored documentation, release notes, and bug } \\
\text { reports associated with each version of software or file stored within the repository }\end{array}$ \\
\hline 6.3 & $\begin{array}{l}\text { The software must provide the user the ability to review, check in, and check out any } \\
\text { version of a file or project that is stored within the repository }\end{array}$ \\
\hline 6.4 & The system must provide the means to rollback files or projects to earlier versions. \\
\hline 7.1 & $\begin{array}{l}\text { The software must provide the user the ability to check out individual files, complete } \\
\text { projects, and installable executables }\end{array}$ \\
\hline 8.1 & $\begin{array}{l}\text { The software must provide the ability to check in new or modified versions of files or } \\
\text { projects }\end{array}$ \\
\hline 8.2 & $\begin{array}{l}\text { The software must limit the ability to check in new versions of stored files to only the } \\
\text { point of contact on record for the stored software }\end{array}$ \\
\hline 9.1 & $\begin{array}{l}\text { The software must be able to correlate all stored documentation, release notes, and bug } \\
\text { reports associated with each version of software or file stored within the repository }\end{array}$ \\
\hline 9.2 & $\begin{array}{l}\text { The system must provide the means for the user to enter and associate tags or keywords } \\
\text { with each file or project within the repository }\end{array}$ \\
\hline 9.3 & The system must provide the ability to search files based upon file dependencies \\
\hline 9.4 & $\begin{array}{l}\text { The system must provide the means for a user to search for files based upon tags, } \\
\text { keywords, file type, classification level, language type, and version notes }\end{array}$ \\
\hline 9.5 & $\begin{array}{l}\text { The system must provide the ability for a user to access and review all version } \\
\text { information for a file or project }\end{array}$ \\
\hline 10.1 & $\begin{array}{l}\text { The system must provide a graphical user's interface that allows a user to add files to the } \\
\text { repository by browsing to the file or dragging the file icon on top of the interface } \\
\text { window }\end{array}$ \\
\hline
\end{tabular}




\begin{tabular}{|c|c|}
\hline Story \# & Constraints / Requirements \\
\hline 10.2 & $\begin{array}{l}\text { During the file and project add process, the system will provide the user with the means } \\
\text { to enter all pedigree information related to the files or projects being added. For each } \\
\text { file or project in the repository, this information will include title, type, language } \\
\text { developed in, purpose or function of the file, projects or program applications that the } \\
\text { files are associated with }\end{array}$ \\
\hline 10.3 & $\begin{array}{l}\text { The system must provide a graphical user's interface that allows a user to enter notes } \\
\text { and comments for each file or project in the repository }\end{array}$ \\
\hline 10.4 & $\begin{array}{l}\text { The system must provide the means for a user to store all files associated with a version } \\
\text { of software including code, executable, and documentation files }\end{array}$ \\
\hline 10.5 & $\begin{array}{l}\text { The system will record and maintain contact information of the person responsible for } \\
\text { each file or project in the repository }\end{array}$ \\
\hline 11.1 & $\begin{array}{l}\text { The system must provide a graphical user's interface that allows users the ability to } \\
\text { easily check in and checkout files or projects }\end{array}$ \\
\hline 11.2 & $\begin{array}{l}\text { During the check in and checkout processes, the system must provide an interface that } \\
\text { allows the user to enter notes concerning the check out or check in of the files }\end{array}$ \\
\hline 11.3 & $\begin{array}{l}\text { The system must be capable of managing multiple versions of each project or file within } \\
\text { the repository }\end{array}$ \\
\hline 11.4 & $\begin{array}{l}\text { The system must provide the ability for users to checkout versions of software or files } \\
\text { for review and use }\end{array}$ \\
\hline 11.5 & $\begin{array}{l}\text { The system must record and maintain checkout and check in information for each } \\
\text { version of the files and projects in the repository. This information shall include at a } \\
\text { minimum user id, date checked out, date checked in, version checked out, version } \\
\text { checked in, and files that were modified during the checkout period }\end{array}$ \\
\hline 12.1 & $\begin{array}{l}\text { The system must be able to store any type of file i.e. text, binary, .bas, .com, .dll, .doc, } \\
\text {.jpg }\end{array}$ \\
\hline 13.1 & $\begin{array}{l}\text { The system must provide the means for the user to enter and associate tags or keywords } \\
\text { with each file or project within the repository }\end{array}$ \\
\hline 13.2 & $\begin{array}{l}\text { The system must provide the means for a user to enter development or version notes } \\
\text { for each file or project stored within the repository }\end{array}$ \\
\hline 13.3 & $\begin{array}{l}\text { The system must provide the means for a user to search for files based upon tags, } \\
\text { keywords, file type, classification level, language type, and version notes }\end{array}$ \\
\hline 13.4 & The system must provide the ability to search files based upon file dependencies \\
\hline 13.5 & $\begin{array}{l}\text { The system will provide the means for a user to request and receive contact information } \\
\text { for each file or project in the repository }\end{array}$ \\
\hline 13.6 & $\begin{array}{l}\text { The system must provide the ability for a user to access and review all version } \\
\text { information for a file or project }\end{array}$ \\
\hline 13.7 & $\begin{array}{l}\text { The system will provide the means to create and maintain relationships between files or } \\
\text { complete projects stored in the repository }\end{array}$ \\
\hline 13.8 & The system will provide the means to search for files or projects by relationships \\
\hline 14 & Covered by user story 13 \\
\hline 15 & Covered by user story 13 \\
\hline
\end{tabular}




\begin{tabular}{|c|c|}
\hline Story \# & Constraints / Requirements \\
\hline 16 & Covered by user story 13 \\
\hline 17 & Covered by user story 13 \\
\hline 18 & Covered by user story 13 \\
\hline 19.1 & The system must be configurable to enable the use of different language compilers \\
\hline 19.2 & The system must be able to build any version of a file or project stored in the repository \\
\hline 20.1 & $\begin{array}{l}\text { The system will automatically notify by email the system administrator and the } \\
\text { responsible contact when a bug is submitted to the system for any file or project }\end{array}$ \\
\hline 20.2 & $\begin{array}{l}\text { The system will provide the means for a user to enter a new bug message into the } \\
\text { system }\end{array}$ \\
\hline 21.1 & $\begin{array}{l}\text { The system will provide the means for a developer or tester to enter the current } \\
\text { disposition of a bug }\end{array}$ \\
\hline 22.1 & $\begin{array}{l}\text { The system will provide the ability for a user to retrieve all bug information associated } \\
\text { with a file or project that is stored within the repository }\end{array}$ \\
\hline 22.2 & $\begin{array}{l}\text { The system will provide the user with the ability to search for files or projects based } \\
\text { upon bug information }\end{array}$ \\
\hline 23.1 & $\begin{array}{l}\text { The system must provide the ability for an administrator to automatically generate usage } \\
\text { reports including number of files checked out, users who currently have files checked } \\
\text { out, number of files or projects in the repository, bug reports, and listing of the names } \\
\text { of files and projects currently in the repository }\end{array}$ \\
\hline 24.1 & The system must be accessible for integration with external systems such as webPMIS \\
\hline 26.1 & $\begin{array}{l}\text { Hardware on which the system will be operating must be capable of being physically } \\
\text { locked up to prevent un-authorized access }\end{array}$ \\
\hline 26.2 & The system must not be dependent upon an Internet connection \\
\hline 26.3 & The system must provide an approved method of access authentication \\
\hline 28.1 & $\begin{array}{l}\text { The system must allow for an administrator or the person responsible for the files or } \\
\text { projects to limit the access to those files and projects }\end{array}$ \\
\hline 28.2 & $\begin{array}{l}\text { The system must allow for the limiting of access based upon role category, user id, } \\
\text { client id, and project id }\end{array}$ \\
\hline
\end{tabular}

\subsection{Technology Evaluation}

With the requirements and constraints defined for the TI Shared Software Component Library, a technical evaluation of existing commercial off the shelf (COTS) library software packages was performed. The first step in this evaluation process was the completion of an open source search using the Internet. Through the use of multiple search criteria, a list of thirty-one potential software candidates was developed. This list consisted of both commercial products such as Microsoft's Team Foundation Server software and open source products like TracSVN. Table 3 provides the full list of applications that were reviewed during the selection process. 
Table 3 Applications reviewed in library software selection.

\begin{tabular}{|l|l|l|l|l|}
\hline TeamForge & $\begin{array}{l}\text { Team Foundation } \\
\text { Server }\end{array}$ & PCMDI & Mercurial & Tortoisehg \\
\hline Git & TortoiseGit & TortoiseSVN & Bazaar & Darcs \\
\hline Monotone & Perforce & TortoiseCVS & Vesta & JEDI \\
\hline GNU Arch & BriefCase 3 Toolkit & SourceJammer & SubVersion & PRCS \\
\hline Aegis & CVS & GNU SCCS & CS-RCS Pro & Atlassian \\
\hline Dimensions CM & Kiln & StarTeam & Vault & Team Coherence \\
\hline TracSVN & & & & \\
\hline
\end{tabular}

The list of candidate applications was further reduced by performing high level reviews against the requirements for each product on the list. This high level review resulted in the list being reduced to three top candidate applications: TeamForge, Team Foundation Server, and TracSVN.

\subsection{Down Selection}

With the identification of the top three candidate applications complete, Trial versions of TeamForge and Team Foundation Server were installed on test machines for the purpose of testing the basic functionality of each application. This installation of the two software applications also provided the team with the opportunity to evaluate the ease in which the applications were installed and configured. TracSVN is an application that is currently in use on a number of projects and as such the project team was already aware of its use and capabilities so it was not included in the trial version of the review.

Following the trial testing, team members tested each of the applications against each functional requirement and reported on which requirements were not being met. Results of this last review showed that TracSVN only met seventy percent of the requirements and Team Foundation Server only met eighty-five percent of the requirements. The TeamForge from Collabnet was the only application that met $100 \%$ of the task requirements. There were two areas in which TeamForge stood out above the other applications, 1) its ease of use, 2) the administration tools that it provides to control access to the system and the objects stored in the repository.

\subsection{Final Selection}

TeamForge provides a web based GUI that allows a user to select and upload a file. There are free to download desktop applications available through CollabNet which will allow drag and drop capabilities for adding files. These applications include versions for Windows desktop, Visual Studio, and Eclipse. The desktop applications provide more functionality than the web base GUI such as being able to drag and drop 
files in order to add them to the repository. All of the desktop applications and the web based interfaces provide the ability for a user to see what tasks, trackers, files, and documents have been submitted by the user as well as the ones assigned to the user. The desktop applications also give the user more methods of viewing and sorting the data and files. In addition, the desktop applications provide graphical user interfaces that allow users to check in and checkout files and code. Using the desktop applications, a user is able to add notes to their check in or check out. The software tracks documents by ID, created by, created date, version, name, size, last edited by, date last edited, and status.

Aside from the usual roles associated with a repository such as administrator, developer, and tester, TeamForge allows the system administrator to define new roles and assign custom access permissions. The software defines user access at two levels, the site administrator level and the project administrator level. At the site administrator level, users are categorized as one of two types, administrator and restricted. Users defined as administrators have unlimited access to all data. Restricted users are limited to accessing only the projects on which they are designated as members. Project managers can add or remove users from accessing the project data as well as defining the user roles associated with the project.

CollabNet, the parent company which develops TeamForge is an established software developer with over ten years of experience and is considered a leader in the development of configuration management and collaboration software. Headquartered in Brisbane, California, CollabNet currently has more than five million users and is in use at more than twenty-five thousand companies world-wide.

Total procurement cost for the TeamForge software was $\$ 5,978.87$. This price included the annual subscription cost of the software for twenty-five user licenses and CollabNet's Platinum support package. The Platinum support package provides the project with 24 hour access to the CollabNet support staff seven days a week as well as providing initial installation assistance.

\subsection{Authentication / Access Control for TICL}

\subsection{Overview}

The intent of this section is to provide a high level overview of the authentication / access control mechanisms that are planned for NA-42 Technical Integration Component Library (TICL). Due to the deficiency in requested vs. actual funding as well as the effects of the continuing resolution (CR) these mechanisms are targeted for implementation in FY12. 


\subsection{Authentication}

A low cost but effective two-factor authentication mechanism is the desired means to handle authentication within TICL. Two-factor authentication implies two independent means of evidence to assert an entity and, in electronic systems, generally takes the form of a user-defined password or Personal Identification Number $(\mathrm{PIN})+$ a value from some sort of physical token. It is our intent to leverage the existing two-factor authentication mechanism already built into WebPMIS as much as possible (given that most of the users of WebPMIS will also be TICL users).

\subsection{Access Control}

TICL will employ a Role-Based Access Control (RBAC) system to control access to specific content (e.g. access to specific projects). As part of the scope we will determine the required level of granularity needed for content control as well as the level of support within the selected COTS solution for TICL (TeamForge). Based on those requirements, a solution will be designed and implemented. Here again, it is our intent to leverage the RBAC mechanisms already built into WebPMIS as much as possible.

\subsection{User Account Management}

The authentication and access control mechanisms within TICL will be designed and implemented such that NA-42 management will have full control over who has access into the system and what content they can create / view / edit.

\section{5. $\quad$ Audit Capabilities}

The TICL authentication and access control mechanisms will provide detailed logging of user activities such that auditing functions can be performed. Examples of logged information would include log-in date / time, content accessed, content created, and functions performed. 


\subsection{References}

2011. CollabNet Overview. www.open.collab.net/about/, Brisbane, California

2011. CollabNet Corporate Overview. www.open.collab.net/media/pdfs/corporate factsheet.pdf, Brisbane, California

2011. CollabNet Support Options. www.open.collab.net/support/support-programs/, Brisbane, California 2011. CollabNet TeamForge 5.4 Project Administrator Guide. www.Carahsoft.com, Reston, Virginia. 2011. CollabNet TeamForge 5.4 System Administrator Guide. www.Carahsoft.com, Reston, Virginia. 2011. CollabNet TeamForge 5.4 Site Administrator Guide. www.Carahsoft.com, Reston, Virginia. 2011. CollabNet TeamForge 5.4 User Guide. www.Carahsoft.com, Reston, Virginia.

2011. NA-42 Technical Integration Software Development Questionnaire. Pacific Northwest National Laboratory. Richland, Washington. 


\subsection{Appendix 1 Technologies Evaluated}

\begin{tabular}{|c|c|c|}
\hline Product & Company & URL \\
\hline TeamForge & COLLABNET & http://www.collab.net/products/ctf/capabilities.html \\
\hline $\begin{array}{l}\text { Team Foundation } \\
\text { Server }\end{array}$ & Microsoft & http://msdn.microsoft.com/en-us/vstudio/ff637362 \\
\hline PCMDI & CDAT & http://www2-pcmdi.IInl.gov/cdat/support/svn \\
\hline mercurial & & http://mercurial.selenic.com/ \\
\hline tortoisehg & Atlassian & https://bitbucket.org/tortoisehg/stable/wiki/Home \\
\hline Git & & http://git-scm.com/ \\
\hline TortoiseGit & & http://code.google.com/p/tortoisegit/ \\
\hline TortoiseSVN & & http://tortoisesvn.net/ \\
\hline Bazaar & & http://bazaar.canonical.com/en/ \\
\hline darcs & & http://darcs.net/ \\
\hline Monotone & & http://www.monotone.ca/ \\
\hline Perforce & & http://www.perforce.com/perforce/downloads/index.html \\
\hline TortoiseCVS & & http://www.tortoisecvs.org/ \\
\hline Vesta & & http://www.vestasys.org/ \\
\hline JEDI & & http://jedivcs.sourceforge.net/ \\
\hline GNU arch & & http://www.gnu.org/software/gnu-arch/ \\
\hline BriefCase 3 Toolkit & & http://www.applied-cs-inc.com/bcintro.html \\
\hline SourceJammer & & http://www.sourcejammer.org// \\
\hline SubVersion & & http://subversion.tigris.org/ \\
\hline PRCS & & http://prcs.sourceforge.net/ \\
\hline Aegis & & http://aegis.sourceforge.net/ \\
\hline CVS & & http://www.nongnu.org/cvs/ \\
\hline GNU SCCS & & http://cssc.sourceforge.net/ \\
\hline CS-RCS Pro & $\begin{array}{l}\text { ComponentSoftware } \\
\text { Inc. }\end{array}$ & http://www.componentsoftware.com/Products/RCS/index.htm \\
\hline Atlassian & & http://www.atlassian.com/about/ \\
\hline Dimensions CM & SERENA & http://www.serena.com/products/dimensions-cm/index.html \\
\hline Kiln & Fog Creek & http://www.fogcreek.com/kiln/ \\
\hline StarTeam & Borland & http://www.borland.com/us/products/starteam/index.aspx \\
\hline Vault & SourceGear & http://www.sourcegear.com/vault/ \\
\hline Team Coherence & QSC & http://www.teamcoherence.com/ \\
\hline Perforce & Perforce & http://www.perforce.com/ \\
\hline
\end{tabular}




\subsection{Appendix 2 TeamForge Price Quote}

COLLABNET.

GOVERNMENT- PRICE QUOTATION

COLLABNET GOVERNMENT at CARAHSOFT

12369 SUNRISE VALLEY DRIVE | SUITE D2 | RESTON, VIRGINIA 20191

PHONE (703) 871-8500 | FAX (703) 871-8505 | TOLL FREE (866) 925-OPEN

WWW.CARAHSOFT.COM |OPENSOURCE@CARAHSOFT.COM

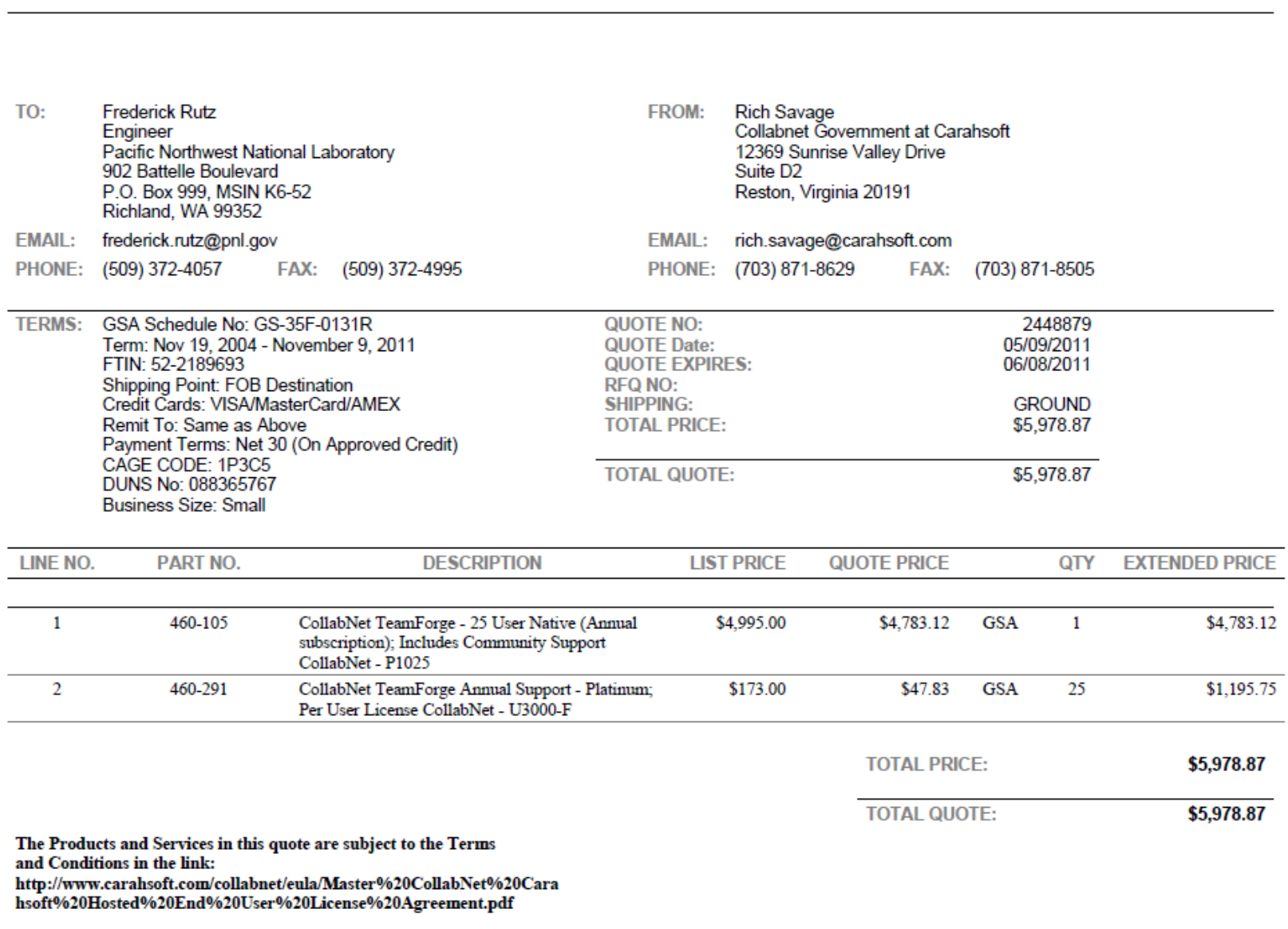

\section{carahsoft}

